\title{
Enhancing Arsenic Solidification/Stabilisation Efficiency of Metallurgical Slag-Based Green Mining Fill and Its Structure Analysis
}

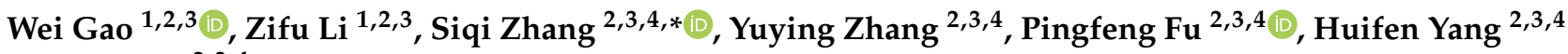 \\ and Wen $\mathrm{Ni}^{2,3,4, *}$ \\ 1 School of Energy and Environmental Engineering, University of Science and Technology Beijing, \\ Beijing 100083, China; 15201455635@163.com (W.G.); zifulee@aliyun.com (Z.L.) \\ 2 Key Laboratory of High-Efficient Mining and Safety of Metal Mines, Ministry of Education, \\ Beijing 100083, China; yuying.zhang@polyu.edu.hk (Y.Z.); pffu@ces.ustb.edu.cn (P.F.); \\ yanghf@ustb.edu.cn (H.Y.) \\ 3 Key Laboratory of Resource-Oriented Treatment of Industrial Pollutants, Beijing 100083, China \\ 4 School of Civil and Resource Engineering, University of Science and Technology Beijing, Beijing 100083, China \\ * Correspondence: zsq2017@ustb.edu.cn (S.Z.); niwen@ces.ustb.edu.cn (W.N.)
}

Citation: Gao, W.; Li, Z.; Zhang, S.; Zhang, Y.; Fu, P.; Yang, H.; Ni, W.

Enhancing Arsenic

Solidification/Stabilisation Efficiency of Metallurgical Slag-Based Green Mining Fill and Its Structure Analysis. Metals 2021, 11, 1389. https:// doi.org/10.3390/met11091389

Academic Editor: Lijie Guo

Received: 8 August 2021

Accepted: 27 August 2021

Published: 1 September 2021

Publisher's Note: MDPI stays neutral with regard to jurisdictional claims in published maps and institutional affiliations.

Copyright: (C) 2021 by the authors. Licensee MDPI, Basel, Switzerland. This article is an open access article distributed under the terms and conditions of the Creative Commons Attribution (CC BY) license (https:/ / creativecommons.org/licenses/by/ $4.0 /)$.
Abstract: To dispose of arsenic-containing tailings with low carbon and high efficiency, sodium sulphate $\left(\mathrm{Na}_{2} \mathrm{SO}_{4}\right)$, sodium hydroxide $(\mathrm{NaOH})$, calcium nitrate $\mathrm{Ca}\left(\mathrm{NO}_{3}\right)_{2}$ and calcium hydroxide $\mathrm{Ca}(\mathrm{OH})_{2}$ were independently added to metallurgical slag-based binder (MSB) solidification/stabilisation (S/S)-treated tailings (MSTs) to enhance the MST arsenic S/S performance. Results showed that only $\mathrm{Ca}(\mathrm{OH})_{2}$ could increase the unconfined compressive strength of MST from 16.3 to 20.49 $\mathrm{MPa}$ and decrease the leachate As concentration from $31 \mu \mathrm{g} / \mathrm{L}$ to below $10 \mu \mathrm{g} / \mathrm{L} . \mathrm{Na}_{3} \mathrm{AsO}_{4} \cdot 12 \mathrm{H}_{2} \mathrm{O}$ and $\mathrm{NaAsO}_{2}$ were used to prepare pure MSB paste for mechanism analysis. The results of microstructure analyses showed the high specific surface area and amorphous properties of calcium-sodium aluminosilicate hydrate facilitated the adsorption or solid-solution formation of $\mathrm{As}(\mathrm{V})$ and $\mathrm{As}(\mathrm{III})$. As(V) formed an inner-sphere complex in ettringite, whereas As(III) formed an outer-sphere complex, and the relatively larger size and charge of $\mathrm{As}(\mathrm{V})$ compared with $\mathrm{SO}_{4}{ }^{2-}$ restrict substitution inside channels without affecting the ettringite structure under high loading of $\mathrm{As}(\mathrm{V})$. The added $\mathrm{Ca}(\mathrm{OH})_{2}$ promoted the hydration reaction of MSBs and facilitated the formation of a $\mathrm{Ca}-\mathrm{As}(\mathrm{V})$ precipitate with low solubility, from $\mathrm{Ca}_{4}(\mathrm{OH})_{2}\left(\mathrm{AsO}_{4}\right)_{2} \cdot 4 \mathrm{H}_{2} \mathrm{O}\left(K_{s p}=10^{-27.49}\right)$ to $\mathrm{Ca}_{5}\left(\mathrm{AsO}_{4}\right)_{3}(\mathrm{OH})\left(K_{s p}=10^{-40.12}\right)$. This work is beneficial for the application of cement-free MSB in the $\mathrm{S} / \mathrm{S}$ process.

Keywords: metallurgical slag-based binders; solidification/stabilisation; As(III); As(V); calcium hydroxide

\section{Introduction}

Arsenic (As) is a toxic and carcinogenic element, which can cause severe effects on human health, such as skin, lungs, kidney and liver cancers, even at a low concentration [1]. The mining, processing and smelting industry of nonferrous metals is the most widespread source of As emissions in China, accounting for 61.8\% [2]. Mining wastewater, smelting slag, dust and tailings are piled up in tailings ponds, which have potential environmental risks and occupy a large percentage of soil [3]. Heavy metal pollution from a large number of tailings poses a major threat to the environment [4,5]. The treatment of heavy metal pollution has received increasing attention since the implementation of the Soil Pollution Prevention and Control Law of the People's Republic of China in 2019 [6]. It is imperative to develop effective and economically viable technologies to reduce pollution from the nonferrous metal industry.

Solidification/stabilisation (S/S) technology has been used to dispose of metal(loid)containing waste by forming a less soluble, mobile or toxic product through adsorption, co-precipitation and physical encapsulation [7]. Ordinary Portland cement (OPC) is a 
traditionally used binder in S/S processes, while the high carbon footprint of cement clinker manufacture is of concern $[8,9]$. To achieve an environment-friendly binder for the $\mathrm{S} / \mathrm{S}$ of As-containing waste, many studies have been conducted to replace cement in part or whole using materials, such as red mud, blast furnace or metakaolin-assisted cement [1,10], cement-free clay-based binders [11], red mud-enhanced magnesium phosphate cement [12], pine sawdust biochar [13], coal fly ash [14], zero-valent iron or magnetic biochar [15]. However, there have been few reports on the use of cement-free metallurgical slag-based binders (MSB) $[16,17]$, which consist of steel slag powder (SSP), ground-granulated blast furnace slag (GGBFS) and flue gas desulphurisation gypsum (FGDG). Steel slag is a byproduct of a steel-making process, known as overburnt clinker because its mineral phase composition is similar to that of cement clinker [18]. In 2019, 149.45 million tonnes of it were produced in China; however, the usage rate is less than 40\% [19]. A large accumulation of steel slag pressurises the environment [20]. GGBFS is a by-product of the steel-making industry and is used as a supplementary cementitious material. In the hydration process of MSB, the relatively high alkalinity of SSP facilitates the breakage of $\mathrm{Si}-\mathrm{O}$ and $\mathrm{Al}-\mathrm{O}$ bonds in the GGBFS vitreous structure to form $\mathrm{SiO}_{4}{ }^{4-}$ and $\mathrm{AlO}_{4}{ }^{5-}$ [21,22], which react with dissolved $\mathrm{Ca}^{2+}$ to form calcium silicoaluminate hydrate $(\mathrm{C}-\mathrm{A}-\mathrm{S}-\mathrm{H})$ gels $[11,23]$. The $\mathrm{AlO}_{4}{ }^{5-}$ dissolved in solution transforms from four coordinated aluminium ions to six coordinated aluminium ions $\left[\mathrm{Al}(\mathrm{OH})_{6}\right]^{3-}$ in alkaline environments, which reacted with the $\mathrm{Ca}^{2+}$ and $\mathrm{SO}_{4}{ }^{2-}$ dissolved from gypsum to form ettringite [24].

In this study, As-containing tailings were chosen as the $\mathrm{S} / \mathrm{S}$ objects, as other hazardous elements' leaching risk is very low after S/S treatment (Table S1). In order to dispose of As-containing tailings with low carbon and high efficiency, the MSB (60 wt\% GGBFS, $30 \mathrm{wt} \% \mathrm{SSP}$, and $10 \mathrm{wt} \%$ FGDG) was chosen as the binder for the As-containing tailings, based on a previous study [25]. $\mathrm{SO}_{4}{ }^{2-}\left(\mathrm{Na}_{2} \mathrm{SO}_{4}\right), \mathrm{OH}^{-}(\mathrm{NaOH}), \mathrm{Ca}^{2+}\left(\mathrm{Ca}\left(\mathrm{NO}_{3}\right)_{2}\right.$ or $\mathrm{Ca}^{2+}$ and $\mathrm{OH}^{-}\left(\mathrm{Ca}(\mathrm{OH})_{2}\right)$ was added to the MSB-S/S treated tailings (MST) to enhance the MST-As-S/S performance. Arsenic in tailing occurs in various states in the natural environment, and its main forms in regard to leaching and migration characteristics are soluble arsenite $\mathrm{As}(\mathrm{III})$ and arsenate $\mathrm{As}(\mathrm{V})$ compounds [26]. The As-S/S mechanism of MSB and the mechanism of efficiency improvement are both unclear; therefore, $\mathrm{Na}_{3} \mathrm{AsO}_{4} \cdot 12 \mathrm{H}_{2} \mathrm{O}$ and $\mathrm{NaAsO}_{2}$ were used to study the $\mathrm{S} / \mathrm{S}$ mechanisms through $\mathrm{X}$-ray diffraction (XRD), Fourier-transform infrared spectroscopy (FTIR) and scanning electron microscope-energy dispersive spectrometer (SEM-EDS) analysis. This study will improve the engineering application prospects of MSB and reusability of MST.

\section{Materials and Methods}

\subsection{As-Containing Tailings and Metallurgical Slag-Based Binders}

As-containing tailings were collected from a closed lead-zinc tailings pond in Hechi Nandan, Guangxi (China). The main components of the tailings were quartz, calcite and fluorite, of which the $\mathrm{D}_{50}$ and $\mathrm{D}_{90}$ particle sizes were 42 and $188 \mu \mathrm{m}$, respectively (Figure S1). The total concentration of As in the tailings was $2098 \mathrm{mg} / \mathrm{kg}$, as determined using an Agilent 7500a ICP-MS (Agilent Technologies, Santa Clara, CA, USA) after aqua regia digestion $\left(1 / 3\right.$ concentrated $\mathrm{HNO}_{3}$ and $\left.\mathrm{HCl}(v / v)\right)$ based on Chinese standard method $\mathrm{HJ}$ 803-2016. The leaching concentration of As in the tailings after horizontal oscillationleaching tests was $0.57 \mathrm{mg} / \mathrm{L}$, based on the Chinese standard method HJ 557-2010 (Table 1). The MSB consisted of GGBFS, SSP and FGDG. The chemical components of raw materials are shown in Table 1, and the XRD spectra of the binders are shown in Figure S2. The analytical reagents, $\mathrm{Na}_{2} \mathrm{SO}_{4}, \mathrm{NaOH}, \mathrm{Ca}\left(\mathrm{NO}_{3}\right)_{2}$ and $\mathrm{Ca}(\mathrm{OH})_{2}$, were used as added additive for the binders, respectively. A polycarboxylic acid water-reducer (WR) was used to achieve an acceptable flowability of mortar during $\mathrm{S} / \mathrm{S}$ treatment. The analytical reagents, $\mathrm{Na}_{3} \mathrm{AsO}_{4} \cdot 12 \mathrm{H}_{2} \mathrm{O}$ and $\mathrm{NaAsO}_{2}$, were used to prepare the pure MSB paste to study the $\mathrm{S} / \mathrm{S}$ mechanisms of $\mathrm{As}(\mathrm{III})$ and $\mathrm{As}(\mathrm{V})$. 
Table 1. Raw material chemical components, blaine fineness, component concentrations and leaching concentration of As.

\begin{tabular}{|c|c|c|c|c|c|}
\hline \multicolumn{2}{|c|}{ Inspected Item } & \multirow{2}{*}{$\begin{array}{c}\text { Tailings } \\
53.23\end{array}$} & \multirow{2}{*}{$\begin{array}{c}\text { GGBFS } \\
33.32\end{array}$} & \multirow{2}{*}{$\frac{\text { SSP }}{17.05}$} & \multirow{2}{*}{$\begin{array}{c}\text { FGDG } \\
2.03\end{array}$} \\
\hline Chemical composition & $\mathrm{SiO}_{2}$ & & & & \\
\hline \multirow[t]{11}{*}{ Oxide $(w t \%)$} & $\mathrm{TiO}_{2}$ & 0.12 & 0.85 & 0.91 & 0.04 \\
\hline & $\mathrm{Al}_{2} \mathrm{O}_{3}$ & 5.07 & 15.43 & 5.73 & 0.78 \\
\hline & $\mathrm{Fe}_{2} \mathrm{O}_{3}$ & 1.65 & 1.01 & 22.33 & 0.48 \\
\hline & $\mathrm{MnO}$ & 0.70 & 0.52 & 3.63 & 0.03 \\
\hline & $\mathrm{MgO}$ & 1.17 & 10.78 & 9.01 & 1.04 \\
\hline & $\mathrm{CaO}$ & 25.49 & 36.89 & 38.42 & 30.01 \\
\hline & $\mathrm{Na}_{2} \mathrm{O}$ & - & 0.49 & 0.16 & 0.06 \\
\hline & $\mathrm{K}_{2} \mathrm{O}$ & 1.38 & 0.38 & 0.09 & 0.15 \\
\hline & $\mathrm{SO}_{3}$ & 1.12 & - & - & 44.97 \\
\hline & $\mathrm{As}_{2} \mathrm{O}_{3}$ & 0.18 & - & - & - \\
\hline & LOI & 10.61 & 0.12 & 1.42 & 22.07 \\
\hline Blaine fineness $\left(\mathrm{m}^{2} / \mathrm{kg}\right)$ & - & - & 435 & 440 & 325 \\
\hline $\mathrm{pH}$ & - & 7.64 & 11.78 & 11.96 & 7.68 \\
\hline \multicolumn{2}{|c|}{ Total As concentration $(\mathrm{mg} / \mathrm{kg})$} & 2098 & - & - & - \\
\hline \multicolumn{2}{|c|}{ As leaching concentration $(\mathrm{mg} / \mathrm{L})$} & 0.57 & - & - & - \\
\hline
\end{tabular}

\subsection{Cement-Free $S / S$ Treatment}

For the preparation of MST mortar samples, the different constituents of binders were mixed with tailings at specific ratios (Table 2). MSB with $60 \mathrm{wt} \%$ GGBFS, $30 \mathrm{wt} \% \mathrm{SSP}$ and $10 \mathrm{wt} \%$ FGDG was chosen due to its high compressive strength, according to the findings of previous studies [25]. Four additives $\left(\mathrm{Na}_{2} \mathrm{SO}_{4}, \mathrm{NaOH}, \mathrm{Ca}\left(\mathrm{NO}_{3}\right)_{2}\right.$ and $\left.\mathrm{Ca}(\mathrm{OH})_{2}\right)$ were incorporated into the MSB mass individually at $5 \mathrm{wt} \%, 10 \mathrm{wt} \%$ and $15 \mathrm{wt} \%$. The binders-to-tailings $(\mathrm{B} / \mathrm{T})$, water-to-solids $(\mathrm{W} / \mathrm{S})$ and WR-to-solids $(\mathrm{WR} / \mathrm{S})$ mass ratios were maintained at $0.25,0.2$ and 0.008 , respectively, in all MST samples. After the tailings and binders were mixed for 1 min using a standard cement mortar mixer, distilled water used to dissolve the WR was added, and the blended mortar was mixed for another $5 \mathrm{~min}$, before being cast into steel moulds $(40 \mathrm{~mm} \times 40 \mathrm{~mm} \times 160 \mathrm{~mm})$ to prepare the MST samples. To prepare MSB paste samples, $5 \mathrm{wt} \%$ concentrations of the analytical reagent, $\mathrm{Na}_{3} \mathrm{AsO}_{4} \cdot 12 \mathrm{H}_{2} \mathrm{O}$ or $\mathrm{NaAsO}_{2}$, was added (Table 2), which were then mixed with water until the mass ratio of water-to-binders $(\mathrm{W} / \mathrm{B})$ reached 0.35 . The paste samples were stirred for $5 \mathrm{~min}$ and then cast into steel moulds $(30 \mathrm{~mm} \times 30 \mathrm{~mm} \times 50 \mathrm{~mm}$ ). All mortar and paste samples were cured in a moist cabinet at $(40 \pm 2){ }^{\circ} \mathrm{C}$ and $(90 \pm 1) \%$ relative humidity (similar to the underground filling environment in Guangxi [27]) for 3 day, and then the samples were demoulded and placed under the same curing conditions until the appropriate degree of sample ageing was achieved.

\subsection{S/S Performance and Spectroscopic/Microscopic Analysis}

The S/S performance was evaluated in terms of the unconfined compressive strength (UCS) and As leachability of the MST samples. The UCS of the samples was assessed on the basis of the Chinese standard GB/T 17671-1999 method of testing cements. The determination of UCS on three replicates at each curing time, and the average value with standard deviations of less than 5\% was reported. The leachability of MST was assessed using the Chinese standard method HJ 557-2010, wherein the ratio of leachant (deionised water) volume to solid specimen weight (crushed to size $<3 \mathrm{~mm}$ ) was maintained at 10:1 ( $/ \mathrm{kg})$. Leachate samples were oscillated horizontally at $110 \pm 10$ times $/ \mathrm{min}$ for $8 \mathrm{~h}$ and then left to stand at room temperature for $16 \mathrm{~h}$. The $\mathrm{pH}$ values were measured, and the leachate was filtered through a $0.45-\mu \mathrm{m}$ polypropylene microfiltration membrane. Afterwards, the filtered leachate samples were acidified to below $\mathrm{pH} 2$ using concentrated $\mathrm{HNO}_{3}$ and then stored at $4{ }^{\circ} \mathrm{C}$ in the dark before As detection using a PerkinElmer Optima 8300 ICP-OES (Perkin Elmer, Cumberland, NJ, USA) or an Agilent 7500a ICP-MS (Agilent Technologies, Santa Clara, CA, USA), with all samples analysed in triplicate to ensure 
accuracy. Mean results for triplicate sample analysis (with standard deviations of less than $5 \%$ ) and error bars, are presented in this study. The As curing rate was evaluated using Equation (1):

$$
\text { Curing Rate }=\left(1-C_{S / S} / C_{T}\right) \times 100 \%
$$

where $C_{s / s}$ is the As leaching concentration of MST, and $\mu \mathrm{g} / \mathrm{L} ; C_{T}$ is the As leaching concentration of untreated tailings.

Table 2. Mixture formulations of MST and MSB samples (wt \%).

\begin{tabular}{|c|c|c|c|c|c|c|c|c|c|c|}
\hline Notation & GGBFS & SSP & FGDG & $\mathrm{Na}_{2} \mathrm{SO}_{4}$ & $\mathrm{NaOH}$ & $\mathrm{Ca}(\mathrm{NC}$ & $\mathrm{Ca}(\mathrm{OH})_{2}$ & $\mathrm{NaAsO}_{2}$ & $\mathrm{Na}_{3} \mathrm{AsO}_{4} \cdot 12 \mathrm{H}_{2} \mathrm{O}$ & Tailing $^{1}$ \\
\hline $\mathrm{T}$ & 60 & 30 & 10 & - & - & - & - & - & - & $1: 4$ \\
\hline T-S1 & 57 & 28.5 & 9.5 & 5 & - & - & - & - & - & 1:4 \\
\hline T-S2 & 54 & 27 & 9 & 10 & - & - & - & - & - & $1: 4$ \\
\hline T-S3 & 51 & 25.5 & 8.5 & 15 & - & - & - & - & - & $1: 4$ \\
\hline T-H1 & 57 & 28.5 & 9.5 & - & 5 & - & - & - & - & $1: 4$ \\
\hline T-H2 & 54 & 27 & 9 & - & 10 & - & - & - & - & $1: 4$ \\
\hline T-H3 & 51 & 25.5 & 8.5 & - & 15 & - & - & - & - & $1: 4$ \\
\hline T-N1 & 57 & 28.5 & 9.5 & - & - & 5 & - & - & - & $1: 4$ \\
\hline T-N2 & 54 & 27 & 9 & - & - & 10 & - & - & - & $1: 4$ \\
\hline T-N3 & 51 & 25.5 & 8.5 & - & - & 15 & - & - & - & $1: 4$ \\
\hline $\mathrm{T}-\mathrm{C} 1$ & 57 & 28.5 & 9.5 & - & - & - & 5 & - & - & $1: 4$ \\
\hline $\mathrm{T}-\mathrm{C} 2$ & 54 & 27 & 9 & - & - & - & 10 & - & - & $1: 4$ \\
\hline T-C3 & 51 & 25.5 & 8.5 & - & - & - & 15 & - & - & $1: 4$ \\
\hline B & 60 & 30 & 10 & - & - & - & - & - & - & 0 \\
\hline B(III) & 57 & 28.5 & 9.5 & - & - & - & - & 5 & - & 0 \\
\hline $\mathrm{B}(\mathrm{V})$ & 57 & 28.5 & 9.5 & - & - & - & - & - & 5 & 0 \\
\hline B-C3 & 51 & 25.5 & 8.5 & - & - & - & 15 & - & - & 0 \\
\hline B-C3(III) & 48.45 & 24.225 & 8.075 & - & - & - & 14.25 & 5 & - & 0 \\
\hline B-C3(V) & 48.45 & 24.225 & 8.075 & - & - & - & 14.25 & - & 5 & 0 \\
\hline
\end{tabular}

${ }^{1}$ Binder-to-tailings mass ratio.

The hydration of pulverised and sieved paste samples was terminated using alcohol drenching at the specific testing age, with samples then dried at $50{ }^{\circ} \mathrm{C}$ under a vacuum for $24 \mathrm{~h}$ for further characterisation. Mineralogy was detected using a high-resolution powered Rigaku D/max-RB XRD with CuK $\alpha$ radiation, a voltage of $40 \mathrm{kV}$, current of $200 \mathrm{~mA}$ and $2 \theta$ scanning, ranging between $10^{\circ}$ and $70^{\circ}$. The morphology and elemental mapping of the samples were analysed using SEM-EDS (JSM-6701F). Structural and chemical bond analyses were performed using GX Perkin-Elmer FTIR (Perkin Elmer, Cumberland, NJ, USA) between wavelengths of $400-4000 \mathrm{~cm}^{-1}$ and at a resolution of $0.125 \mathrm{~cm}^{-1}$.

\section{Results}

\subsection{The S/S Performance of MST Samples}

The UCS results for MST samples (Figure 1a) demonstrate that MST combined with various additives performed differently. The 3, 7 and 28 day UCS results for T were $11,13.8$ and $16.3 \mathrm{MPa}$, respectively. An increase in concentrations of $\mathrm{Na}_{2} \mathrm{SO}_{4}, \mathrm{NaOH}$ and $\mathrm{Ca}\left(\mathrm{NO}_{3}\right)_{2}$ reduced the USC of MST at every curing time, especially for the addition of $\mathrm{NaOH}$, which inhibits hydration reactions and reduced the USC of MST (the lowest 28 day USC (T-H3 3.7 MPa) was only $22.7 \%$ of T). The addition of $\mathrm{Ca}(\mathrm{OH})_{2}$ enhanced mechanical properties (the highest $28 \mathrm{~d}$ UCS (T-C3 $20.49 \mathrm{MPa}$ ) was $125.7 \%$ of T). The USC of all samples could meet the filling requirements (5 MPa, the black line in Figure 1a), except for T-H3. 

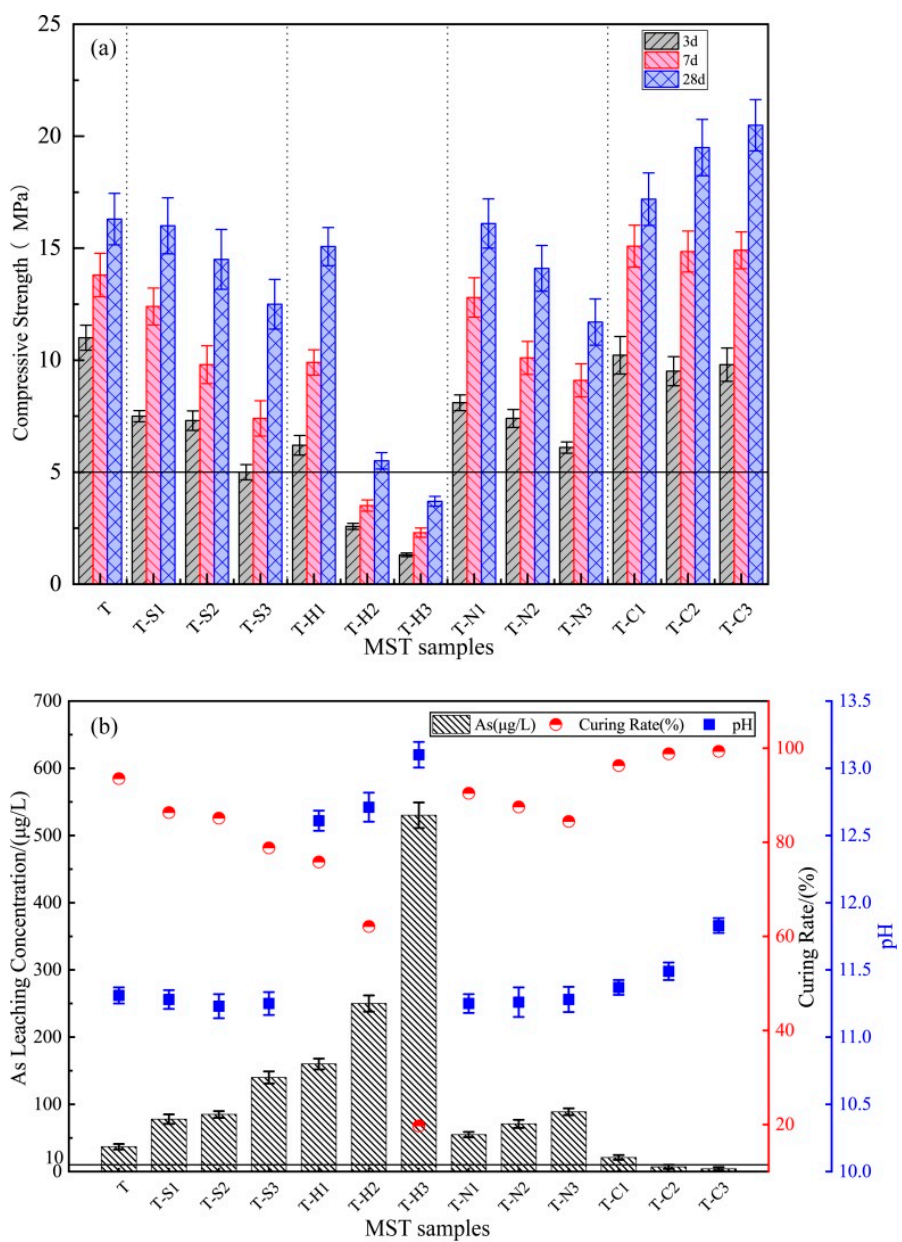

Figure 1. (a) UCS of MST samples at 3, 7 and 28 day; (b) As leachability of 28 day MST samples.

Figure $1 \mathrm{~b}$ shows leachate As concentrations and the $\mathrm{pH}$ values of 28 day MST samples after the horizontal oscillation-leaching experiments. The leachate As concentration of $\mathrm{T}$ samples was $31 \mu \mathrm{g} / \mathrm{L}$, which exceeded the prescribed As concentration limit value in the Chinese standard GB 5749-2006 for drinking water quality $(10 \mu \mathrm{g} / \mathrm{L}$, the black line in Figure 1b), indicating a relevant risk of environmental pollution. The addition of $\mathrm{Na}_{2} \mathrm{SO}_{4}, \mathrm{NaOH}$ or $\mathrm{Ca}\left(\mathrm{NO}_{3}\right)_{2}$ enhanced leachate As concentration, particularly that of T-H3, which reached $530 \mu \mathrm{g} / \mathrm{L}$. The addition of $\mathrm{Ca}(\mathrm{OH})_{2}$ reduced the leachate As concentration, particularly that of T-C2 and T-C3, which was less than $10 \mu \mathrm{g} / \mathrm{L}$.

\subsection{Spectroscopic/Microscopic Analysis}

\subsubsection{XRD Pattern Analysis}

The XRD patterns of MSB paste hydrated for 3 and 28 day are presented in Figure 2a,b), respectively. The main mineral phases of the $\mathrm{B}$ sample, as shown in Figure $2 \mathrm{a}$, are C-S-H gel, ettringite $\left(\mathrm{Ca}_{6} \mathrm{Al}_{2}\left(\mathrm{SO}_{4}\right)_{3}(\mathrm{OH})_{12} \cdot 26 \mathrm{H}_{2} \mathrm{O}\right)$ and un-hydrated gypsum $\left(\mathrm{CaSO}_{4} \cdot 2 \mathrm{H}_{2} \mathrm{O}\right)$, $\mathrm{C}_{2} \mathrm{~F}\left(2 \mathrm{CaO} \cdot \mathrm{Fe}_{2} \mathrm{O}_{3}\right)$, $\mathrm{RO}$ phase $\left((\mathrm{MgO})_{0.239}(\mathrm{FeO})_{0.761}\right)$, akermanite $\left(\mathrm{Ca}_{2} \mathrm{MgSi}_{2} \mathrm{O}_{7}\right)$ and $\mathrm{C}_{2} \mathrm{~S}$ $\left(2 \mathrm{CaO} \cdot \mathrm{SiO}_{2}\right)$ (Figure S2). With the addition of $\mathrm{As}(\mathrm{III})$ (sample $\mathrm{B}(\mathrm{III})$ ), the peaks of ettringite decreased. However, when $\mathrm{As}(\mathrm{V})$ was added $(\mathrm{B}(\mathrm{V}))$, the peaks of ettringite disappeared due to the formation of a new phase, $\left(\mathrm{Ca}_{4} \mathrm{Al}_{2} \mathrm{SO}_{10} \cdot 16 \mathrm{H}_{2} \mathrm{O}\right)$, and the peaks of $\mathrm{Ca}-\mathrm{As}$ coprecipitation $\mathrm{Ca}_{4}(\mathrm{OH})_{2}\left(\mathrm{AsO}_{4}\right)_{2} \cdot 4 \mathrm{H}_{2} \mathrm{O}$ appeared. 

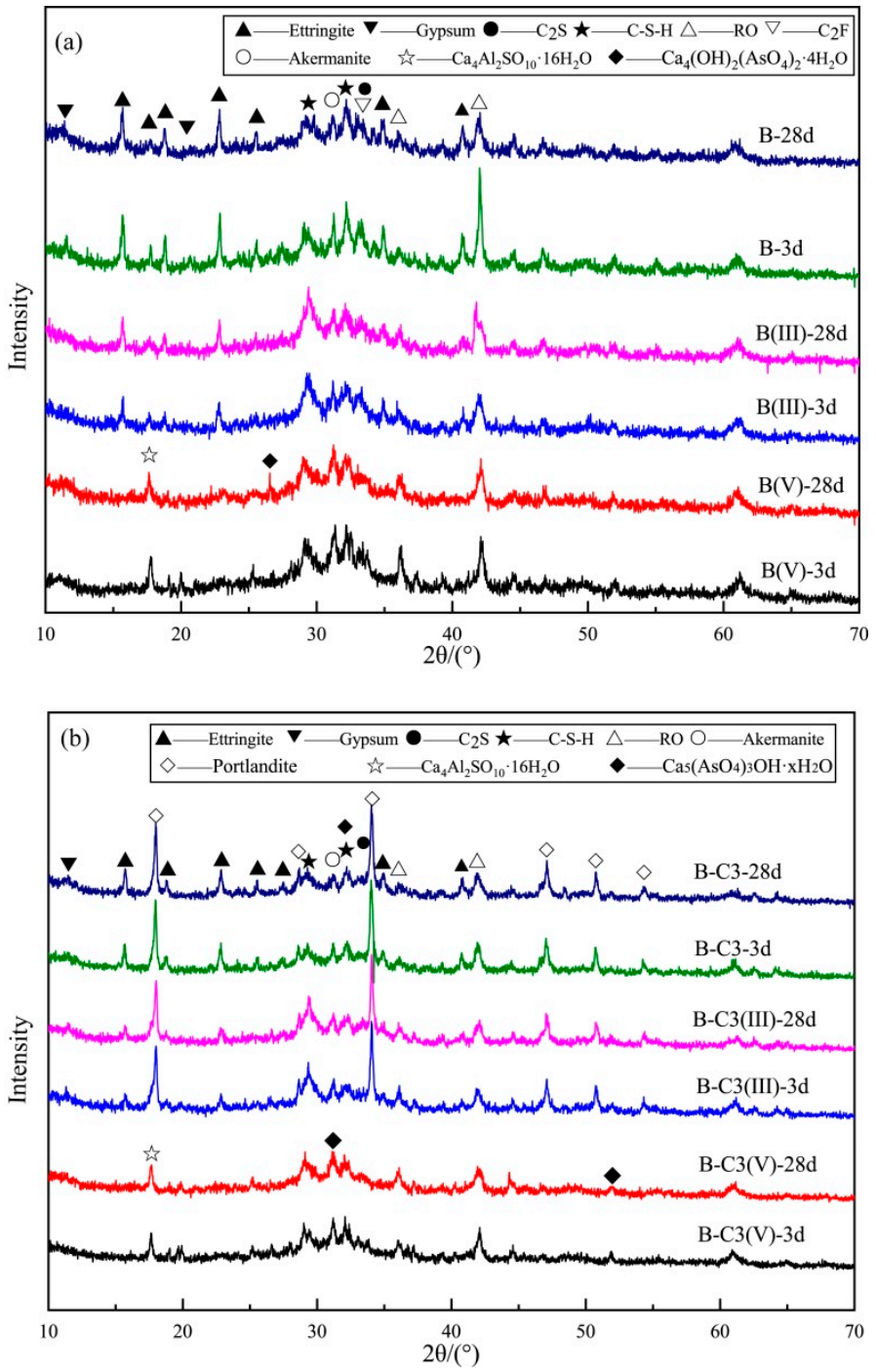

Figure 2. The XRD patterns of (a) B, B(III) and B(V) paste; (b) B-C3, B-C3(III) and B-C3(V) paste.

Compared with Figure 1a, the added $\mathrm{Ca}(\mathrm{OH})_{2}$ characteristic peaks appeared in the XRD patterns of B-C3 and B-C3-(III); however, it did not appear in B-C3(V) (Figure 2b), and the peaks of $\mathrm{Ca}-\mathrm{As}$ co-precipitation $\mathrm{Ca}_{5}\left(\mathrm{AsO}_{4}\right)_{3} \mathrm{OH} \cdot \mathrm{xH}_{2} \mathrm{O}$ appeared.

\subsubsection{FTIR Spectra Analysis}

Figure 3a displays the FTIR spectra of the $\mathrm{B}, \mathrm{B}(\mathrm{III})$ and $\mathrm{B}(\mathrm{V})$ samples. The spectra of the six samples are similar, presenting analogous adsorption bands. The pure $\mathrm{B}$ paste spectra (Figure 3a (1) and (2) exhibit a small band at $3639 \mathrm{~cm}^{-1}$ associated with the $\mathrm{O}-\mathrm{H}$ stretching vibration; bands at 3424 and $1646 \mathrm{~cm}^{-1}$ are related to the $\mathrm{O}-\mathrm{H}$ stretching and bending modes of molecular interlayer water, respectively, and bands near $1450(1478,1428) \mathrm{cm}^{-1}$ and at $876 \mathrm{~cm}^{-1}$ are related to the anti-symmetric stretching $\left(\mathrm{v}_{3}\right)$ and out-of-plane bending $\left(\mathrm{v}_{2}\right)$ modes of $\mathrm{CO}_{3}{ }^{2-}$ ions, respectively. The bands at $973 \mathrm{~cm}^{-1}$ and near $450(462,422) \mathrm{cm}^{-1}$ are associated with anti-symmetric $\mathrm{Si}-\mathrm{O}(\mathrm{Al})$ stretching vibrations $\left(\mathrm{v}_{3}\right)$ and in-plane $\mathrm{Si}-\mathrm{O}$ bending vibrations $\left(\mathrm{v}_{2}\right)$ in the $\mathrm{SiO}_{4}$ tetrahedra of the $\mathrm{C}-(\mathrm{A})-\mathrm{S}-\mathrm{H}$ gel. The lack of a sharp band at $973 \mathrm{~cm}^{-1}$ indicates the wide distribution of $\mathrm{SiQ}^{n}(\mathrm{mAl})$ units. Moreover, the 3 day and 28 day infra-red spectra of $B$ samples display large bands at $1114 \mathrm{~cm}^{-1}$ corresponding to the $\mathrm{S}-\mathrm{O}_{4}$ stretching mode $\left(\mathrm{v}_{3}\right)$, with a shoulder at $537 \mathrm{~cm}^{-1}$, potentially due to out-ofplane $\mathrm{Si}-\mathrm{O}$ bending vibrations $\left(\mathrm{v}_{4}\right)$. 

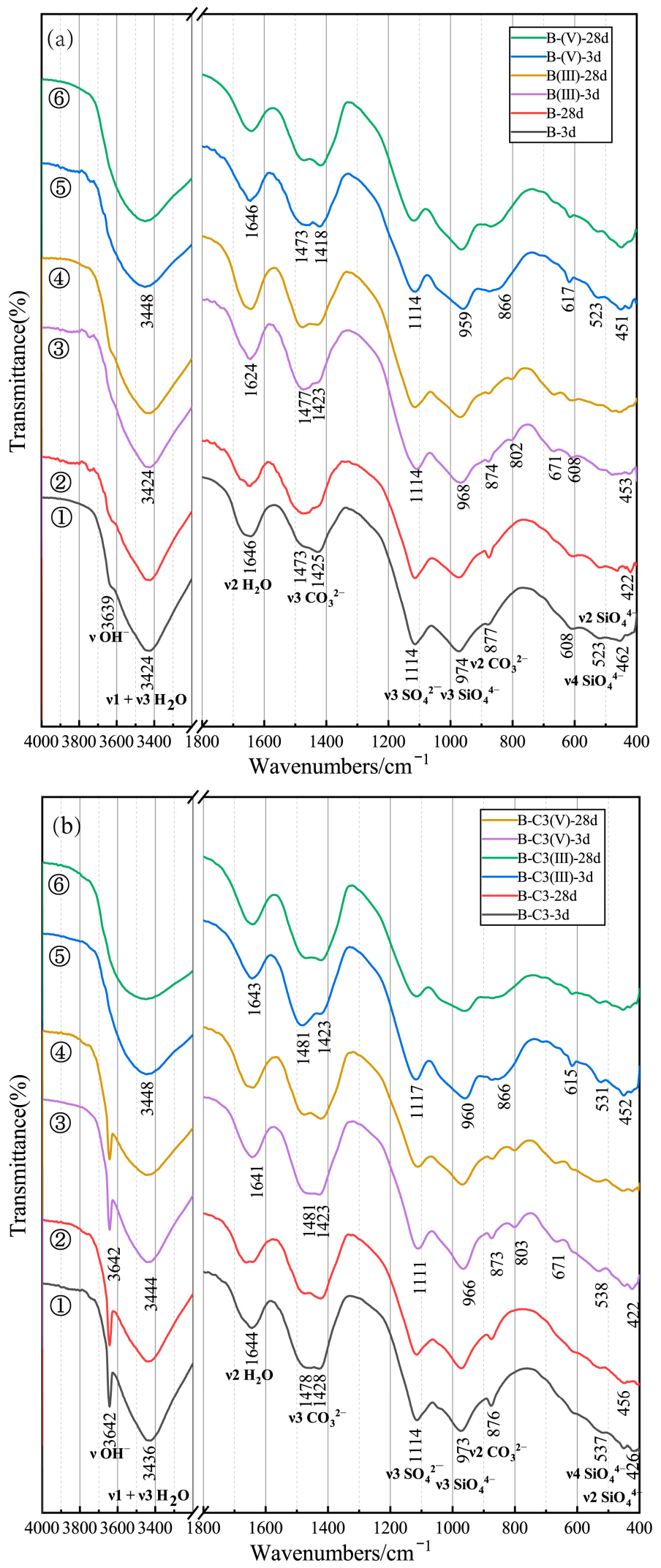

Figure 3. FTIR spectra of (a) (1) and (2) B sample, (3) and (4) B(III) sample and (5) and (6) B(V) sample; (b) (1) and (2) B-C3 sample, (3) and (4) B-C3(III) sample and (5) and (6) B-C3(V) sample.

Nevertheless, some differences were observed in the infrared spectra of $\mathrm{B}(\mathrm{III})$ and $\mathrm{B}(\mathrm{V})$ samples. The weak band at $3639 \mathrm{~cm}^{-1}$ in the B sample (Figure 3a (1) and (2)) disappeared 
in the $\mathrm{B}(\mathrm{V})$ (Figure 3a (5) and (6) samples, indicating that $\mathrm{OH}^{-}$reacts with the added $\mathrm{As}(\mathrm{V})$, which is consistent with the result of XRD analysis (Figure 2a). The anti-symmetric $\mathrm{Si}-\mathrm{O}(\mathrm{Al})$ stretching vibrations $\left(\mathrm{v}_{3}\right)$ of the $\mathrm{C}-(\mathrm{A})-\mathrm{S}-\mathrm{H}$ gel $\left(973 \mathrm{~cm}^{-1}\right.$ for $\left.\mathrm{B}\right)$ decreased to $968 \mathrm{~cm}^{-1}$ for $\mathrm{B}(\mathrm{III})$ and $964 \mathrm{~cm}^{-1}$ for $\mathrm{B}(\mathrm{V})$, indicating that the added As(III) and As(V) were combined in the microstructure network and changed the degree of polymerisation of the $\mathrm{C}-(\mathrm{A})-\mathrm{S}-\mathrm{H}$ gel. In addition, the $\mathrm{O}-\mathrm{H}$ stretching band $\left(3424 \mathrm{~cm}^{-1}\right.$ for $\left.\mathrm{B}\right)$ increased to $3448 \mathrm{~cm}^{-1}$ and became broader for $\mathrm{B}(\mathrm{V})$ due to the absence of ettringite, leading to the change of interchannel molecular water, which combined with the result of XRD pattern (Figure 2a). Moreover, some new bands were observed, with the appearance of broadband at 802 and $671 \mathrm{~cm}^{-1}$ for B(III), and at $866 \mathrm{~cm}^{-1}$ for B(V) (Figure 3a (3)-(6)), which was due to the As-O stretching vibration of the As(III) and As(V) species [28,29].

Figure 3 b display the FTIR spectra of the B-C3, B-C3(III) and B-C3(V) samples, respectively. These spectra are all similar to those presented in Figure 3a, except that the spectra of the B-C3 and B-C3(III) samples exhibited sharp adsorption bands at $3642 \mathrm{~cm}^{-1}$ due to the addition of $\mathrm{Ca}(\mathrm{OH})_{2}$. However, the sharp adsorption bands at $3642 \mathrm{~cm}^{-1}$ did not appear in $\mathrm{B}-\mathrm{C} 3(\mathrm{~V})$, illustrating that $\mathrm{Ca}(\mathrm{OH})_{2}$ reacted with $\mathrm{As}(\mathrm{V})$. Bands around $1110 \mathrm{~cm}^{-1}$, corresponding to the $\mathrm{S}-\mathrm{O}_{4}$ stretching mode (v3) in Figure $3 \mathrm{~b}$ (1)-6), were offset at $1114 \mathrm{~cm}^{-1}$ in B-C3 sample, $1111 \mathrm{~cm}^{-1}$ in B-C3(III) and $1117 \mathrm{~cm}^{-1}$ in B-C3(V), indicating that, after As(III) and $\mathrm{As}(\mathrm{V})$ were added, the hydration products associated with $\mathrm{SO}_{4}{ }^{2-}$ were affected, as shown by the XRD pattern (Figure $2 b$ ).

\subsubsection{SEM-EDS Analysis}

Figure 4 show SEM-EDS images for B, B(V) and B(III) at hydration ages of 3 and 28 day. Dense structures with amorphous gels and needle-like mineral phases are visible in the cement-free B paste in Figure $4 a, b$, which are calcium-sodium aluminosilicate hydrate $(\mathrm{C}-(\mathrm{N})-\mathrm{A}-\mathrm{S}-\mathrm{H})$ gels and ettringite, combined with the component analysis results in Table S2 (b-1, b-2 and b-3). After As(V) was added, the needle-like ettringite structure was undetected (Figure 4c,d), and a small amount of As(V) was found in the short columnar crystals of sodium sulphate, combined with the component analysis results (Table S2 (d-1)). Moreover, according to the SEM-EDS mapping images (Figure S3) of the red box in Figure $4 \mathrm{~d}$, the distribution of $\mathrm{As}(\mathrm{V})$ was almost similar to that of $\mathrm{Ca}, \mathrm{Si}$ and $\mathrm{Al}$, and the distribution of $\mathrm{Na}$ was similar to that of $\mathrm{S}$. Therefore, the majority of the added As(V) entered the C-A-S-H gels through isomorphism substitution or was adsorbed and encapsulated by the gels, whereas the tiny minority of that entered the sodium sulphate to form sodium arsenic alunite. After As(III) was added, combined with the component analysis results (Table S2 (e-1,f-3)), different amounts of As(III) were detected in the C-A-S-H, ettringite, $\mathrm{Na}_{2} \mathrm{SO}_{4}$ and $\mathrm{Na}_{2} \mathrm{Ca}\left(\mathrm{SO}_{4}\right)_{2}$ (Figure $4 \mathrm{e}, \mathrm{f}$ ).

Figure 5 show SEM-EDS images of B-C3, B-C3(V) and B-C3(III) at hydration ages of 3 and 28 day. In addition, amorphous $\mathrm{C}-\mathrm{A}-\mathrm{S}-\mathrm{H}$ gels interwoven with needle-like ettringite structures were detected in the B-C3 paste. The images of B-C3(V) and B-C3(III) are similar to those for $\mathrm{B}(\mathrm{V})$ and $\mathrm{B}(\mathrm{III})$, except for the appearance of calcium hydroxide flakes in $\mathrm{B}$ C3(V)-3d (Figure 5c) and calcium monosulfoaluminate hydrate (AFm) flakes in B-C3(III)-3d (Figure 5e), combined with the component analysis results in Table S3, which may be due to their content being lower than the detection limit of the XRD technique; both kinds of flakes disappeared as the hydration reaction proceeded. 

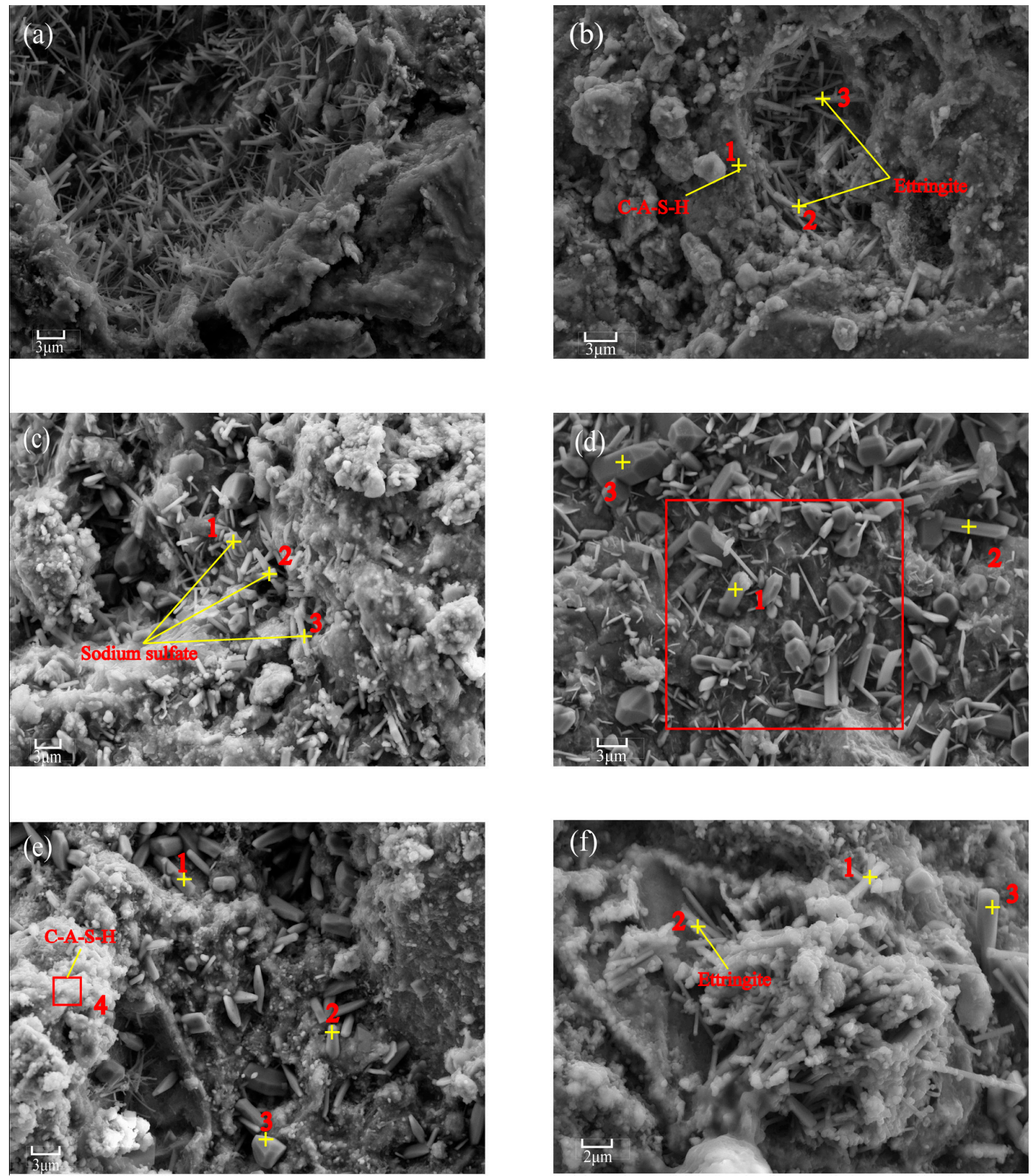

Figure 4. SEM-EDS result for (a) B-3d; (b) B-28 d; (c) B(V)-3 d; (d) B(V)-28 d; (e) B(III)-3 d; (f) B(III)-28 d. 

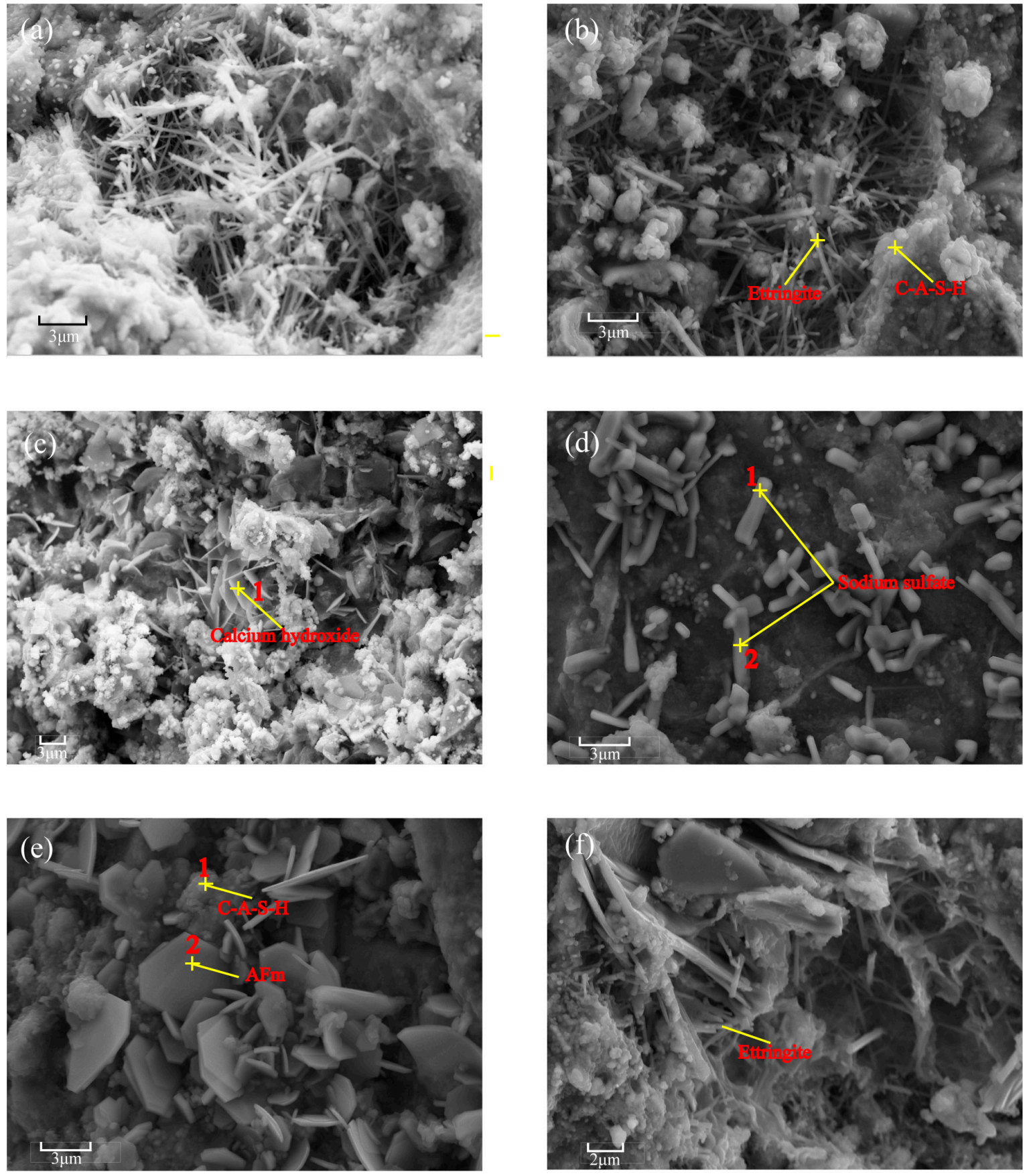

Figure 5. SEM-EDS result for (a) B-C3-3 d; (b) B-C3-28 d; (c) B-C3(V)-3 d; (d) B-C3(V)-28 d; (e) B-C3(III)-3 d; (f) B-C3(III)-28 d.

\section{Discussion}

This study demonstrates the different As S/S performance of MST samples after four additives $\left(\mathrm{Na}_{2} \mathrm{SO}_{4}, \mathrm{NaOH}, \mathrm{Ca}\left(\mathrm{NO}_{3}\right)_{2}\right.$ and $\left.\mathrm{Ca}(\mathrm{OH})_{2}\right)$ were added, as shown in Table S4. The MSB is selective for additives and only $\mathrm{Ca}(\mathrm{OH})_{2}$ exerted a positive effect on the As $\mathrm{S} / \mathrm{S}$ performance. The addition of $\mathrm{Na}_{2} \mathrm{SO}_{4}$ had little effect on the $\mathrm{pH}$ values, UCS and As curing rate, probably because gypsum in the MSB system (10 wt $\%$ FGDG in B) was sufficient to provide sulphate for the hydration reaction. The addition of $\mathrm{NaOH}$ resulted in a $\mathrm{pH}$ value above 13 , which inhibited the dissolution of $\mathrm{Ca}^{2+}$ and hindered the hydration reaction, leading to a sharp decrease in UCS [30]. The amphoteric nature of arsenic in an alkaline environment and repulsion by $\mathrm{OH}^{-}$during the adsorption process of the hydration products led to the sharp decrease of the As curing rate [31,32]. Neither $\mathrm{NaOH}$ 
nor $\mathrm{Ca}\left(\mathrm{NO}_{3}\right)_{2}$ improved the As S/S performance, confirming that the individual addition of $\mathrm{OH}^{-}$without $\mathrm{Ca}^{2+}$ would not improve As S/S efficiency and had a negative effect [33,34].

In addition, this study demonstrates that both the $\mathrm{As}(\mathrm{V})$ and $\mathrm{As}(\mathrm{III}) \mathrm{S} / \mathrm{S}$ mechanism of MSB, and the effect of $\mathrm{Ca}(\mathrm{OH})_{2}$ addition on $\mathrm{As}(\mathrm{V})$ and $\mathrm{As}(\mathrm{III}) \mathrm{S} / \mathrm{S}$ are different. The addition of $\mathrm{Ca}(\mathrm{OH})_{2}$ to MSB raised the $\mathrm{pH}$ of the reaction mixture (Figure 1), facilitated GGBFS dissolution and provided a source of $\mathrm{Ca}^{2+}$, thus improving the $\mathrm{As}(\mathrm{V})$ and $\mathrm{As}(\mathrm{III})$ $\mathrm{S} / \mathrm{S}$ related to the hydration products. Adsorption or solid solution formation of $\mathrm{As}(\mathrm{V})$ and $\mathrm{As}(\mathrm{III})$ occurred due to the high specific surface area and amorphous properties of $\mathrm{C}-\mathrm{A}-\mathrm{S}-\mathrm{H}$, based on the shift in anti-symmetric $\mathrm{Si}-\mathrm{O}(\mathrm{Al})$ stretching vibrations (v3) in the discussion above (Figure 3) and SEM-EDS results (Figures 4 and 5).

Anion substitution in ettringite can occur via reaction with surface sites (ligand exchange), replacing $\mathrm{Al} / \mathrm{Ca}$ coordinated surface $\mathrm{OH}^{-}$or substituting for sulphate inside channels (isomorphic substitution) [35]. This occurs as the ettringite surfaces are negatively charged under alkaline $\mathrm{pH}$ range conditions and due to the column and channel-like structure of ettringite, which is composed of columns of $\mathrm{Ca}_{6}\left[\mathrm{Al}(\mathrm{OH})_{6}\right]_{2} \cdot 24 \mathrm{H}_{2} \mathrm{O}^{6+}$ and channels of $\left[\left(\mathrm{SO}_{4}\right)_{3} \cdot 2 \mathrm{H}_{2} \mathrm{O}\right]^{6-}$ [36]. The extent of channel substitution of ettringite may be inversely proportional to the difference in size and electronegativity of the oxyanion compared with $\mathrm{SO}_{4}{ }^{2-}(0.29 \AA)$, resulting in $\mathrm{As}(\mathrm{V})(0.47 \AA)$ being likelier to be channelsubstituted with sulphur than $\mathrm{As}(\mathrm{III})(0.69 \AA)$ [37]. Thus, As(V) tended to form an innersphere complex in ettringite, whereas As(III) could form an outer-sphere complex [38], and the relatively larger size and charge of $\mathrm{As}(\mathrm{V})$ compared with $\mathrm{SO}_{4}{ }^{2-}$ restricts the substitution inside channels without affecting the ettringite structure under high loading of $\mathrm{As}(\mathrm{V})$, which is consistent with the XRD, IR and SEM-EDS analysis results.

Previous studies [39-41] have verified the formation of Ca-As precipitates under alkaline conditions. In the present study, the distinct $\mathrm{Ca}-\mathrm{As}$ (III) mineral phase characteristic peak was not found in the XRD patterns, maybe because of the content being below the detection limit of $\mathrm{XRD}$ analysis or mainly existing as an amorphous or more complex structure. When $\mathrm{Ca}(\mathrm{OH})_{2}$ was added, $\mathrm{Ca}-\mathrm{As}(\mathrm{V})$ changed from $\mathrm{Ca}_{4}(\mathrm{OH})_{2}\left(\mathrm{AsO}_{4}\right)_{2} \cdot 4 \mathrm{H}_{2} \mathrm{O}\left(K_{s p}=10^{-27.49}\right)$ to $\mathrm{Ca}_{5}\left(\mathrm{AsO}_{4}\right)_{3}(\mathrm{OH})\left(K_{s p}=10^{-40.12}\right)$ (Figure 2), which restricted As leaching [42].

Based on the findings of this study, alkaline solid waste with high calcium ion equilibrium concentrations and high alkalinity can be used to replace $\mathrm{Ca}(\mathrm{OH})_{2}$ added to MSB for the $\mathrm{S} / \mathrm{S}$ of high As-containing solid wastes for low carbon and environmental protection.

\section{Conclusions}

In this study, the effects of four additives $\left(\mathrm{Na}_{2} \mathrm{SO}_{4}, \mathrm{NaOH}, \mathrm{Ca}\left(\mathrm{NO}_{3}\right)_{2}\right.$ or $\left.\mathrm{Ca}(\mathrm{OH})_{2}\right)$ on the As S/S performance of MST to enhance the As S/S efficiency were investigated. As-containing analytical reagents were used to prepare pure MSB paste to study the S/S mechanisms of $\mathrm{As}(\mathrm{III})$ and $\mathrm{As}(\mathrm{V})$ and the mechanism of efficiency improvement using $\mathrm{Ca}(\mathrm{OH})_{2}$, based on XRD, IR and SEM-EDS analysis. Based on the results obtained from this study, the following conclusions can be drawn:

- An MSB is selective for the additives, and only $\mathrm{Ca}(\mathrm{OH})_{2}$ exerts a positive effect on the $\mathrm{S} / \mathrm{S}$ performance of MST.

- $\quad \operatorname{As}(\mathrm{V})$ can form an inner-sphere complex in ettringite, whereas As(III) can form an outer-sphere complex, and the relatively larger size and charge of $\mathrm{As}(\mathrm{V})$ compared with $\mathrm{SO}_{4}{ }^{2-}$ restrict its substitution inside channels without affecting the ettringite structure under high loading of $\mathrm{As}(\mathrm{V})$.

- The added $\mathrm{Ca}(\mathrm{OH})_{2}$ facilitates the encapsulation and adsorption of $\mathrm{As}(\mathrm{V})$ and $\mathrm{As}(\mathrm{III})$ in MSB, and changes the $\mathrm{Ca}-\mathrm{As}(\mathrm{V})$ from $\mathrm{Ca}_{4}(\mathrm{OH})_{2}\left(\mathrm{AsO}_{4}\right)_{2} \cdot 4 \mathrm{H}_{2} \mathrm{O}\left(K_{s p}=10^{-27.49}\right)$ to $\mathrm{Ca}_{5}\left(\mathrm{AsO}_{4}\right)_{3}(\mathrm{OH})\left(K_{s p}=10^{-40.12}\right)$.

- Cement-free MSB with $\mathrm{Ca}(\mathrm{OH})_{2}$ added is feasible to dispose of high As-containing solid wastes with high efficiency and a low carbon footprint. 
Supplementary Materials: The following are available online at https:/ / www.mdpi.com/article/10 .3390/met11091389/s1, Figure S1: (a) XRD pattern and (b) grain size results of tailings, Figure S2: The XRD pattern of raw materials: (a) ground granulated blast furnace slag (GGBFS), $\mathrm{C}_{2} \mathrm{~S}$ : dicalcium silicate; (b) steel slag powder (SSP), $\mathrm{C}_{3} \mathrm{~A}$ : tricalcium aluminate, $\mathrm{RO}$ phase: $(\mathrm{MgO})_{0.239}(\mathrm{FeO})_{0.761}, \mathrm{C}_{2} \mathrm{~S}$ : dicalcium silicate, $\mathrm{C}_{2} \mathrm{~F}$ : dicalcium ferrite; (c) flue gas desulfurisation gypsum (FGDG), Figure S3: The SEM-EDS electron image and mapping images of Figure 4 (d), Table S1: Leached concentration of raw materials and $\mathrm{T}$ in Table 2, Table S2: Component analysis result of point in the Figure 4, Table S3: Component analysis result of point in the Figure 5, Table S4: Assessment summary of the S/S performance effects of $\mathrm{Na}_{2} \mathrm{SO}_{4}, \mathrm{NaOH}, \mathrm{Ca}\left(\mathrm{NO}_{3}\right)_{2}$ and $\mathrm{Ca}(\mathrm{OH})_{2}$ at different doses $(w \mathrm{t} \%)$.

Author Contributions: Formal analysis, W.G.; funding acquisition, P.F. and H.Y.; investigation, W.G. and Y.Z.; methodology, W.G.; project administration, S.Z.; resources, S.Z.; supervision, S.Z.; validation, W.G., Z.L., S.Z. and W.N.; writing-original draft, W.G.; writing-review and editing, Z.L., S.Z. and W.N. All authors have read and agreed to the published version of the manuscript.

Funding: This work was funded by the National Key Research and Development Program of China, grant number 2020YFC1807804 and the National Key Research and Development Program of China, grant number 2019YFC1803503.

Institutional Review Board Statement: Not applicable.

Informed Consent Statement: Not applicable.

Data Availability Statement: Not applicable.

Acknowledgments: Special thanks are addressed to Xuming Ma and Qihui Yan for their support with the interpretation of XRD results.

Conflicts of Interest: The authors declare no conflict of interest.

\section{References}

1. Wang, L.; Chen, L.; Tsang, D.C.; Zhou, Y.; Rinklebe, J.; Song, H.; Kwon, E.E.; Baek, K.; Ok, Y.S. Mechanistic insights into red mud, blast furnace slag, or metakaolin-assisted stabilization/solidification of arsenic-contaminated sediment. Environ. Int. 2019, 133, 105247. [CrossRef]

2. Ministry of Ecology and Environment of the People's Republic of China. Annual Report on Environmental Statistics. 2017. Available online: http:/ / www.mee.gov.cn/hjzl/sthjzk/sthjtjnb/ (accessed on 8 August 2021).

3. Cheng, X.; Qi, W.; Huang, Q.; Zhao, X.; Fang, R.; Xu, J. Typical Geo-Hazards and Countermeasures of Mines in Yunnan Province, Southwest China. IOP Conf. Ser. Earth Environ. Sci. 2016, 44, 022008. [CrossRef]

4. Xiao, R.; Wang, S.; Li, R.; Wang, J.; Zhang, Z. Soil heavy metal contamination and health risks associated with artisanal gold mining in Tongguan, Shaanxi, China. Ecotoxicol. Environ. Saf. 2017, 141, 17-24. [CrossRef] [PubMed]

5. Kan, X.; Dong, Y.; Feng, L.; Zhou, M.; Hou, H. Contamination and health risk assessment of heavy metals in China's lead-zinc mine tailings: A meta-analysis. Chemosphere 2021, 267, 128909. [CrossRef] [PubMed]

6. Wang, Y. Status and countermeasures on soil heavy metals pollution control in nonferrous metals industry in China. Nonferrous Met. 2021, 3, 1-9. [CrossRef]

7. Shi, C.; Spence, R. Designing of Cement-Based Formula for Solidification/Stabilization of Hazardous, Radioactive, and Mixed Wastes. Crit. Rev. Environ. Sci. Technol. 2004, 34, 391-417. [CrossRef]

8. Habert, G.; Miller, S.A.; John, V.M.; Provis, J.L.; Favier, A.; Horvath, A.; Scrivener, K.L. Environmental impacts and decarbonization strategies in the cement and concrete industries. Nat. Rev. Earth Environ. 2020, 1, 559-573. [CrossRef]

9. Andrew, R.M. Global $\mathrm{CO}_{2}$ emissions from cement production. Earth Syst. Sci. Data 2018, 10, 195-217. [CrossRef]

10. Li, J.-S.; Chen, L.; Zhan, B.; Wang, L.; Poon, C.S.; Tsang, D.C. Sustainable stabilization/solidification of arsenic-containing soil by blast slag and cement blends. Chemosphere 2021, 271, 129868. [CrossRef]

11. Wang, L.; Cho, D.-W.; Tsang, D.C.; Cao, X.; Hou, D.; Shen, Z.; Alessi, D.; Ok, Y.S.; Poon, C.S. Green remediation of As and Pb contaminated soil using cement-free clay-based stabilization/solidification. Environ. Int. 2019, 126, 336-345. [CrossRef] [PubMed]

12. Wang, L.; Chen, L.; Guo, B.; Tsang, D.C.; Huang, L.; Ok, Y.S.; Mechtcherine, V. Red mud-enhanced magnesium phosphate cement for remediation of $\mathrm{Pb}$ and as contaminated soil. J. Hazard. Mater. 2020, 400, 123317. [CrossRef]

13. Beiyuan, J.; Awad, Y.M.; Beckers, F.; Tsang, D.; Ok, Y.S.; Rinklebe, J. Mobility and phytoavailability of As and Pb in a contaminated soil using pine sawdust biochar under systematic change of redox conditions. Chemosphere 2017, 178, 110-118. [CrossRef] [PubMed]

14. Tsang, D.C.W.; Yip, A.; Olds, W.E.; Weber, P. Arsenic and copper stabilisation in a contaminated soil by coal fly ash and green waste compost. Environ. Sci. Pollut. Res. 2014, 21, 10194-10204. [CrossRef] 
15. Li, J.; Zhang, Y.; Wang, F.; Wang, L.; Liu, J.; Hashimoto, Y.; Hosomi, M. Arsenic immobilization and removal in contaminated soil using zero-valent iron or magnetic biochar amendment followed by dry magnetic separation. Sci. Total Environ. 2021, 768, 144521. [CrossRef]

16. Criado, M.; Ke, X.; Provis, J.; Bernal, S.A. Alternative inorganic binders based on alkali-activated metallurgical slags. In Sustainable and Nonconventional Construction Materials using Inorganic Bonded Fiber Composites; Elsevier: Amsterdam, The Netherlands, 2017; pp. 185-220. [CrossRef]

17. Zhou, M.; Cheng, X.; Chen, X. Studies on the Volumetric Stability and Mechanical Properties of Cement-Fly-Ash-Stabilized Steel Slag. Materials 2021, 14, 495. [CrossRef]

18. Yildirim, I.Z.; Prezzi, M. Chemical, Mineralogical, and Morphological Properties of Steel Slag. Adv. Civ. Eng. 2011, 2011, 463638. [CrossRef]

19. Yang, S.; Zhang, B.; Yang, Y.; Liu, M.; Tang, G.; Liu, X. Research on the status of comprehensive utilization of steel slag. Ind. Miner. Process. 2021, 4, 31-35. [CrossRef]

20. Jiang, Y.; Ling, T.-C.; Shi, C.; Pan, S.-Y. Characteristics of steel slags and their use in cement and concrete-A review. Resour. Conserv. Recycl. 2018, 136, 187-197. [CrossRef]

21. Wang, S.; Wang, C.; Wang, Q.; Liu, Z.; Qian, W.; Jin, C.; Chen, L.; Li, L. Study on Cementitious Properties and Hydration Characteristics of Steel Slag. Pol. J. Environ. Stud. 2018, 27, 357-364. [CrossRef]

22. Li, Y.; Ni, W.; Gao, W.; Zhang, Y.; Yan, Q.; Zhang, S. Corrosion evaluation of steel slag based on a leaching solution test. Energy Sources Part A Recover. Util. Environ. Eff. 2018, 41, 790-801. [CrossRef]

23. Wang, L.; Geddes, D.; Walkley, B.; Provis, J.L.; Mechtcherine, V.; Tsang, D.C. The role of zinc in metakaolin-based geopolymers. Cem. Concr. Res. 2020, 136, 106194. [CrossRef]

24. Nguyen, H.; Carvelli, V.; Kunther, W.; Illikainen, M.; Kinnunen, P. Phase evolution and mechanical performance of an ettringitebased binder during hydrothermal aging. Cem. Concr. Res. 2021, 143, 106403. [CrossRef]

25. Gao, W.; Ni, W.; Zhang, Y.; Li, Y.; Shi, T.; Li, Z. Investigation into the semi-dynamic leaching characteristics of arsenic and antimony from solidified/stabilized tailings using metallurgical slag-based binders. J. Hazard. Mater. 2019, 381, 120992. [CrossRef] [PubMed]

26. Wang, K.; Wang, Y.; Wan, Y.; Mi, Z.; Wang, Q.; Wang, Q.; Li, H. The fate of arsenic in rice plants (Oryza sativa L.): Influence of different forms of selenium. Chemosphere 2020, 264, 128417. [CrossRef]

27. Zhang, Y.; Zhang, S.; Ni, W.; Yan, Q.; Gao, W.; Li, Y. Immobilisation of high-arsenic-containing tailings by using metallurgical slag-cementing materials. Chemosphere 2019, 223, 117-123. [CrossRef]

28. NanrRu, Y.; WenrHai, Y. The Handbook of Inorganic Matalloid Material Atlas; Wuhan University of Technology Press: Wuhan, China, 2000.

29. Zhang, G.-S.; Qu, J.-H.; Liu, H.-J.; Liu, R.-P.; Li, G.-T. Removal Mechanism of As(III) by a Novel Fe-Mn Binary Oxide Adsorbent: Oxidation and Sorption. Environ. Sci. Technol. 2007, 41, 4613-4619. [CrossRef]

30. Guan, X.; Chen, J.; Gao, Y.; Gao, J. Mechanical properties and microstructure of coal gangue mortar blocks excited by NaOH Alkali. J. Xi An Univ. Sci. Technol. 2020, 40, 658-664.

31. Yazdani, M.R.; Tuutijärvi, T.; Bhatnagar, A.; Vahala, R. Adsorptive removal of arsenic (V) from aqueous phase by feldspars: Kinetics, mechanism, and thermodynamic aspects of adsorption. J. Mol. Liq. 2016, 214, 149-156. [CrossRef]

32. Phearom, S.; Shahid, M.K.; Choi, Y.-G. Optimization of Arsenic Adsorption by Mill Scale-Derived Magnetite Particles Using Response Surface Methodology. J. Hazard. Toxic Radioact. Waste 2021, 25, 04021022. [CrossRef]

33. Yi, Y.; Shi, J.; Tian, Q.; Guo, X.-Y. Arsenic removal from high-arsenic dust by NaOH-Na $2 \mathrm{~S}$ alkaline leaching. Chin. J. Nonferrous Met. 2015, 25, 806-814.

34. Zhang, W.; Ma, B.; Wang, C. Thermodynamics analysis on formation of calcium arsenate slag. Nonferrous Met. 2019, 9, 61-66. [CrossRef]

35. Avalos, N.M.; Varga, T.; Mergelsberg, S.T.; Silverstein, J.A.; Saslow, S.A. Behavior of iodate substituted ettringite during aqueous leaching. Appl. Geochem. 2020, 125, 104863. [CrossRef]

36. Saslow, S.A.; Kerisit, S.N.; Varga, T.; Mergelsberg, S.T.; Corkhill, C.L.; Snyder, M.M.V.; Avalos, N.M.; Yorkshire, A.S.; Bailey, D.J.; Crum, J. Immobilizing Pertechnetate in Ettringite via Sulfate Substitution. Environ. Sci. Technol. 2020, 54, 13610-13618. [CrossRef]

37. Jiménez, A.; Prieto, M. Thermal Stability of Ettringite Exposed to Atmosphere: Implications for the Uptake of Harmful Ions by Cement. Environ. Sci. Technol. 2015, 49, 7957-7964. [CrossRef] [PubMed]

38. Guo, B.; Sasaki, K.; Hirajima, T. Selenite and selenate uptaken in ettringite: Immobilization mechanisms, coordination chemistry, and insights from structure. Cem. Concr. Res. 2017, 100, 166-175. [CrossRef]

39. Li, Y.-C.; Min, X.-B.; Chai, L.-Y.; Shi, M.-Q.; Tang, C.-J.; Wang, Q.-W.; Liang, Y.-J.; Lei, J.; Liyang, W.-J. Co-treatment of gypsum sludge and $\mathrm{Pb} / \mathrm{Zn}$ smelting slag for the solidification of sludge containing arsenic and heavy metals. J. Environ. Manag. 2016, 181, 756-761. [CrossRef]

40. Lei, J.; Peng, B.; Min, X.; Liang, Y.; You, Y.; Chai, L. Modeling and optimization of lime-based stabilization in high alkaline arsenic-bearing sludges with a central composite design. J. Environ. Sci. Health Part. A 2017, 52, 1-10. [CrossRef]

41. Lei, J.; Peng, B.; Liang, Y.-J.; Min, X.-B.; Chai, L.-Y.; Ke, Y.; You, Y. Effects of anions on calcium arsenate crystalline structure and arsenic stability. Hydrometallurgy 2018, 177, 123-131. [CrossRef]

42. Cornelis, G.; Johnson, C.A.; Van Gerven, T.; Vandecasteele, C. Leaching mechanisms of oxyanionic metalloid and metal species in alkaline solid wastes: A review. Appl. Geochem. 2008, 23, 955-976. [CrossRef] 